April - $\mathbf{2 0 1 9}$

\title{
Competency Profile of the Digital and Online Teacher in Future Education
}

\author{
Mohamed Ally \\ Visiting Scholar, Advanced Innovation Centre for Future Education, \\ Beijing Normal University, China \\ and \\ Professor, Athabasca University, Canada
}

\begin{abstract}
As education progresses in the digital era and in the Fourth Industrial Revolution, learning will be adaptive and individualized to meet the needs of individual learners. This is possible because of emerging technology, artificial intelligence, and the internet of things. This study is making significant contribution to future education by identifying forces that are shaping education and developing a competency profile for the digital teacher of the future. The research conducted focus groups and interviews with education experts from six countries to identify the forces shaping education in the future and the competencies required by the digital teacher to function effectively. The Competency Profile for the Digital Teacher (CPDT) can be used to train and orient the digital teacher of the future.
\end{abstract}

Keywords: digital teacher, online teacher, teacher competencies, 21st century education, fourth industrial revolution, future education, online learning 


\section{Introduction}

There are many forces that are placing a sense of urgency on the education system to transform itself for the future, which will drastically change the role of the teacher. Some of these forces include the Fourth Industrial Revolution (Schmidt, 2017; World Economic Forum, 2017), innovative pedagogies (Maldonado-Mahauad, Perez-Sanagustín, Kizilcec, Morales, \& Munoz-Gama., 2018; Suárez, Specht, Prinsen, Kalz, \& Ternier, 2018), information explosion due to the increasing use of the internet (Reyna, Hanham, \&Meier, 2018), lifelong learning (Berry, 2018; Hinzen \& Schmitt, 2016), artificial intelligence (Schmidt, 2017), and the move to open education resources (McGreal, 2017; Paskevicius \&HodgkinsonWilliams, 2018; Redecker, 2017). This study identified necessary competencies of digital and online teachers who must adapt to the Internet and digital technologies of the future.

Educators need to look into the future to determine what should be done to be relevant and serve society in the future. The education system will be preparing learners for jobs that do not exist today because of emerging technologies, information explosion, and the Fourth Industrial Revolution. The demand for lifelong learning is growing significantly around the world since to get meaningful jobs citizens need to obtain current and relevant education (Kolenick, 2018; Patterson, 2018). As a result, countries are starting to implement digital learning technology to educate their citizens for success in the 21st century. As education moves towards the goal of "education for all' and to help achieve the United Nation's Sustainable Development Goal 4 to provide quality education for all, there will be increasing use of digital technology especially for learners who live in remote locations and for those who cannot physically attend school because of a lack of infrastructure (Gaskell, 2018; UNESCO, 2015). Such a future will require that teachers be trained to use digital technology to provide virtual education to learners in remote areas and for nomadic learners (Ally \&Tsinakos, 2014; Dyer, 2016). With technology, the learners, rather than the teachers, are at the center of learning; they develop their knowledge base and create an understanding of the world by being active learners (Anagün, 2018; Guo, 2018; McWilliams, 2016). Accessibility and flexibility of learning opportunities means that learners can decide when and where to learn.

The digital era will call for "digital" teachers who must adapt to education in the future. According to Mitra (2014), education will be self-organizing, and technology will play a major role in the delivery of education and in providing support to learners. Additionally, learning will move toward individualization and learner-centeredness because of artificial intelligence, learning analytics, and the Internet of things (Chai \& Kong, 2017; Mitra, 2014; Popenici \& Kerr, 2017; Srinivasan, 2017).

Based on the data collected in this study, this paper will present both general and digital competencies that will be required by digital teachers of the future. The competency profile presented in this paper can be used to train or orient future teachers so that they move education into the Fourth Industrial Revolution. This study was guided by two research questions: (1) What are some of the forces shaping the future of education? and (2) What competencies (knowledge and skills) are required by digital teachers of the future? 


\section{Literature Review}

As technology emerges in the Fourth Industrial Revolution and new pedagogical approaches are developed, the role of the teacher will change to provide quality, flexible education. The literature review that follows focuses on areas of the field that guide this evolution.

\section{Learner-Centered Education}

Although learner-centered education is being practiced today (Boling \& Beatty, 2010; Bonnici, Maatta, Klose, Julien, \& Bajjaly, 2016), emerging technologies will make learning in the future adaptive and more individualized because of the use of smart learning technologies (Gros, 2016; Hwang, 2014). This will allow learners to learn at their peak learning times rather than going to a specific location at a specific time to learn. Some learners' have their peak learning time in the evening while others have theirs in the early morning. The World Innovative Summit in Education (WISE) conducted a survey on School in 2030 with 645 experts in different sectors from around the world (Qatar Foundation, 2014) in which $83 \%$ of the experts reported that they believed learning will be individualized to meet individual learner's need. The majority of experts said that teachers will be a guide for learning rather than a deliverer of information; since learning materials will primarily be in digital format, learners will be able to use the technology to access learning materials, transforming the teacher's role into a facilitator of learning. Based on the results of this survey, the education system should provide learners with the skills to learn independently.

\section{The Role of the Teacher in the Fourth Industrial Revolution}

According to the World Economic Forum (2017), the Fourth Industrial Revolution is changing the world because new technologies that combine the physical, digital, and biological worlds are impacting all disciplines, economies, and industries. To cope with these pervasive changes, education, towards the year 2030, must prepare teachers to educate learners to function effectively in the Fourth Industrial Revolution. Training for digital teachers for the future may take place in formal teacher training programs or in professional development undertaken throughout lifelong learning (Chai \& Kong, 2017; Kramer \&Tamm, 2018). Countries around the world are investing in teacher professional development to ensure that teachers are prepared for the future (Kong, Looi, Chan, \& Huang, 2017). Professional development will be increasingly important for teachers in the digital age in order that they may stay abreast of quality and flexible education strategies for more sophisticated learners (Halterbran, 2017; Inverso, Kobrin, \& Hashmi, 2017; Patterson, 2018).

The digital teacher must be able to educate students in a virtual environment using emerging digital technologies (Campbell \& Cameron, 2016). In courses such as Chemistry and Biology, teachers can use virtual reality technology to allow students to do a virtual walk-through of experiments or body systems (Parong \& Mayer, 2018). In a history course, the teacher can use augmented reality technology to give students a virtual experience of historical events or a tour of a history museum (Capuano, Gaeta, Guarino, Miranda, \& Tomasiello, 2016). With the increasing use of digital technology and a global movement toward the use of open education resources (OER), learners will satisfy their information needs from digital sources rather than be obliged to rely on a single teacher. The "middle (wo)man" can be easily skipped in the search for information; open education practice (OEP) will become the norm (Cronin, 2017; Ehlers, 2011).

Although in constructivist paradigms and in much adult learning, the role of the teacher has become a facilitator of learning, this trend will become more predominant, and "the guide on the side" will focus 
on providing help to individual learners in need of assistance. In addition, the teacher of the future must be able to use emerging technologies such as wearable devices to teach students difficult topics, such as in the science areas. One such device is 3-D glasses using augmented reality (AR) where students experience real objects virtually. Yoon, Anderson, Lin, \&Elinich, (2017) conducted a study to investigate the effectiveness of AR in teaching science concepts and found that students in the AR group performed better on knowledge tests than students in the non-AR group. Their findings showed that AR enhanced students' ability to visualize details and find hidden information, concluding that digital augmentation had a positive effect on students' content knowledge.

Learners today are the "always-on" generation. Emerging technologies in education, such as those mentioned above, allow learning spaces to exist anywhere and anytime. Teachers and their systems must be prepared to educate the current and upcoming generations of learners who are technology literate and have experience playing digital games and viewing high quality videos. Teachers of the future must learn to be comfortable using educational games and social media as innovative and interactive strategies for teaching (Crompton, Lin, Burke, \& Block, 2018; De Troyer, Van Broeckhoven, \&Vlieghe, 2017; Yam, Swati, \&Jing, 2014). As learning opportunities become more ubiquitous because of mobile and wearable devices, the learning cell model will be useful for organizing and deploying learning resources (Chen, Yu, \& Chiang, 2016; Yu, Yang, Cheng, \& Wang 2015; Yu, Ally, \& Tsinakos, 2018).

In order to prepare learners to function in the $21^{\text {st }}$ century, teachers in the digital age should also be prepared to develop the "whole" learner. Ferrández-Berrueco and Sánchez-Tarazaga (2014) identified four competency areas for teachers that include subject competency, methodological competency, social competency, and personal competency. In a globalized digital era, where technology allows services, production, and processes in organizations to become automated, learners' digital skills must be comprehensive and inclusive (Anagün, 2018; Guo, 2018; McWilliams, 2016).

Education will be self-organizing in a smart learning environment where learners will assume control over their own learning; hence, their needs will be individualized and perhaps more demanding (Gros, 2016; Hwang, 2014; Mitra, 2014). Smart learning environments can be regarded as

the technology-supported learning environments that make adaptations and provide appropriate support (e.g., guidance, feedback, hints or tools) in the right places and at the right time based on individual learners' needs, which might be determined via analyzing their learning behaviors, performance and the online and real-world contexts in which they are situated. (Hwang, 2014, p. 5).

At the same time, because of the exponential information explosion, information will be updating at a rapid pace, which will require continuous re-learning and updated learning, as well as "smart" education (Gros, 2016; Huang, 2018). As learners interact with smart education systems, the system will be capable of learning about the learner and providing the appropriate intervention (Hwang, 2014). However, a foreseeable barrier to innovation of this type could be the teachers' lack of functioning skills with this new technology (Farias, 2016; Hunt, 2006). Ultimately, the World Economic Forum foresees that teachers will need to adapt to artificial intelligence and robotics in order to successfully make the transition to teach successfully and appropriately in the Fourth Industrial Revolution (World Economic Forum, 2017). 


\section{Methodology}

Data were collected from 34 experts from six countries (Austria, Canada, China, Greece, Malaysia, and Sweden). The experts were selected based on their expertise using innovative technologies to teach, with experience using emerging technologies and innovative pedagogies such as MOOCs (Massive Open Online Courses), artificial intelligence, augmented reality, virtual reality, online learning, and mobile learning. Most of the experts were involved in training teachers, instructional designers, and instructors to prepare them to implement innovative technologies in their own courses. This qualitative study used focus groups, interviews, and written responses to collect data.. The international input gathered was important for this study since the intention was to develop a competency profile that can be used globally.

Interviews were conducted on a one-to-one basis and lasted between 20 to 30 minutes. The focus groups, which involved small groups of experts, lasted 30 minutes. The written responses were provided on an individual basis; hence, it is not known how long the experts spent to specify the competencies. The experts were asked to think ahead to the year 2030 and suggest competencies that the digital teacher will require to provide quality and flexible education to learners. During the sessions, the researcher documented the competencies provided by participants. The experts also mentioned forces that are impacting the future of education and therefore will affect the skills required by teachers. The competencies listed were then organized into major themes, which formed the major areas for the competency profile. Based on the input from the experts, a draft competency profile was developed and was presented to two expert teachers to validate. The competencies were revised based on the minor suggestions provided by the expert teachers who validated the competencies.

\section{Results}

\section{Forces Shaping the Future of Education}

The experts mentioned a variety of forces that are shaping the future of education, forces which they feel will impact the skills required by future teachers to provide quality education and support to learners (Figure 1). 
Ally

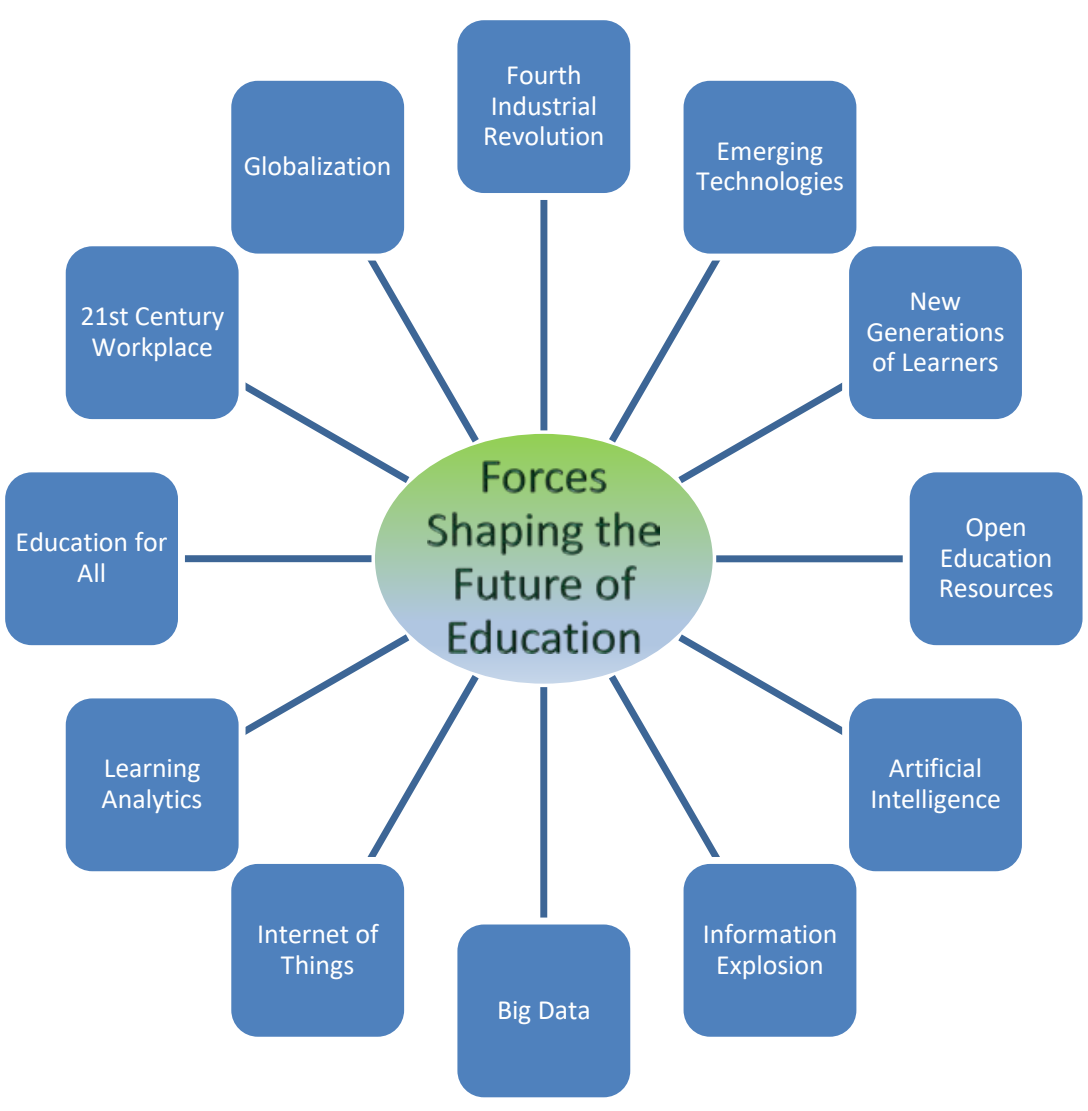

Figure 1. Forces shaping the future of education.

The experts identified nine major themes that indicate the major areas of responsibilities for the digital teacher of the future (Figure 2) and 105 competencies that fall within the major themes. The following sections present the major areas of responsibilities followed by a list of competencies that fall within each major area. 


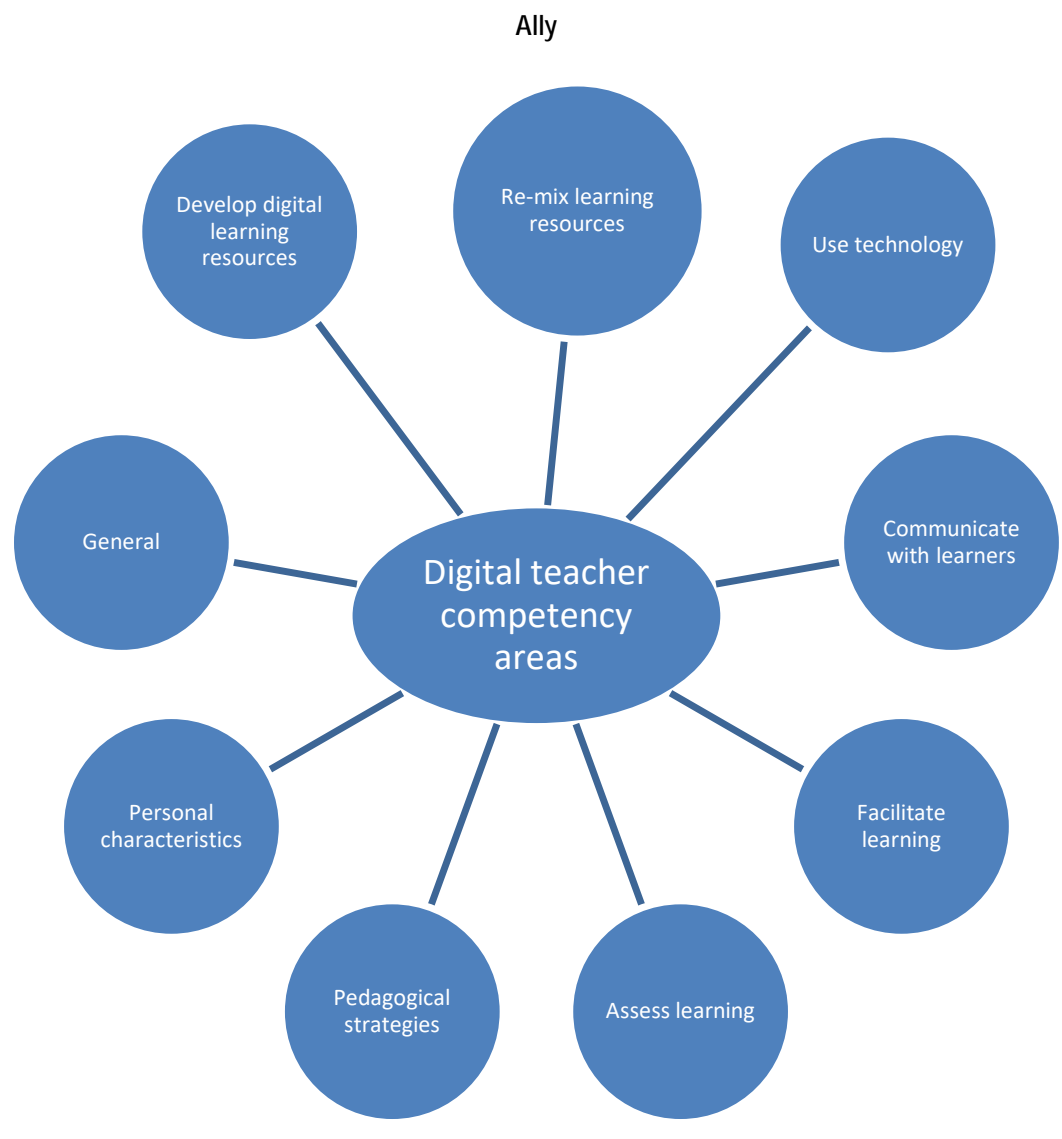

Figure 2. Major areas of responsibilities for the digital teacher of the future.

\section{Competencies Required by Digital Teachers for Future Education}

General. The data shows that digital teachers will need to have some general qualities that will allow them to provide quality support virtually to learners. This study identified 12 general competencies for the digital teacher of the future (Figure 3).

\begin{tabular}{|l|l|l|l|l|}
\hline A. General & $\begin{array}{l}\text { A1. Be comfortable } \\
\text { working in a virtual } \\
\text { environment. }\end{array}$ & $\begin{array}{l}\text { A2. Provide } \\
\text { support of } \\
\text { learners } \\
\text { regardless of } \\
\text { location and time. }\end{array}$ & $\begin{array}{l}\text { A3. Work from } \\
\text { anywhere and at } \\
\text { any time. }\end{array}$ & $\begin{array}{l}\text { A4. Teach students } \\
\text { life skills. }\end{array}$ \\
\hline $\begin{array}{l}\text { A5. Keep up with } \\
\text { emerging learning } \\
\text { technologies to use } \\
\text { in education. }\end{array}$ & $\begin{array}{l}\text { A6. Keep current } \\
\text { in the content } \\
\text { area to facilitate } \\
\text { learning. }\end{array}$ & $\begin{array}{l}\text { A7. Encourage } \\
\text { students to be good } \\
\text { citizens. }\end{array}$ & $\begin{array}{l}\text { A8. Basic } \\
\text { knowledge of } \\
\text { artificial } \\
\text { intelligence. }\end{array}$ \\
\hline $\begin{array}{l}\text { A9. State of the art } \\
\text { (current) knowledge } \\
\text { in the subject area. }\end{array}$ & $\begin{array}{l}\text { A10. Collaborate } \\
\text { virtually with } \\
\text { other teachers to } \\
\text { share information } \\
\text { on learners' } \\
\text { progress. }\end{array}$ & $\begin{array}{l}\text { A11. Share effective } \\
\text { learning practices } \\
\text { with other teachers. }\end{array}$ & $\begin{array}{l}\text { A12. Prepare } \\
\text { learners to live in } \\
\text { harmony with the } \\
\text { environment. }\end{array}$ \\
\hline
\end{tabular}

Figure 3. Digital teacher general competencies. 
Use digital technology. In the digital era, especially in the Fourth Industrial Revolution, the teacher should be digitally literate to use technology to deliver and support education. This study identified 15 competencies for the digital teacher under the area "Use Digital Technology" (Figure 4).

\begin{tabular}{|l|l|l|l|l|}
\hline $\begin{array}{l}\text { B. Use digital } \\
\text { technology }\end{array}$ & $\begin{array}{l}\text { B1. Be digitally } \\
\text { literate. }\end{array}$ & $\begin{array}{l}\text { B2. Integrate } \\
\text { technology in the } \\
\text { curriculum } \\
\text { seamlessly. }\end{array}$ & $\begin{array}{l}\text { B3. Be comfortable } \\
\text { when using } \\
\text { technology. }\end{array}$ & $\begin{array}{l}\text { B4. Use learning } \\
\text { analytics to monitor } \\
\text { individual learner } \\
\text { progress. }\end{array}$ \\
\hline & $\begin{array}{l}\text { B5. Use assistive } \\
\text { technology to } \\
\text { provide support to } \\
\text { learners with } \\
\text { special needs. }\end{array}$ & $\begin{array}{l}\text { B6. Integrate } \\
\text { augmented } \\
\text { reality, virtual } \\
\text { reality, and mixed } \\
\text { reality to give } \\
\text { learners a real life } \\
\text { experience. }\end{array}$ & $\begin{array}{l}\text { B7. Troubleshoot } \\
\text { basic technology } \\
\text { problems. }\end{array}$ & $\begin{array}{l}\text { B8. Adapt to } \\
\text { emerging } \\
\text { technologies. }\end{array}$ \\
\hline $\begin{array}{l}\text { B9. Use multimedia } \\
\text { technologies to } \\
\text { deliver learning } \\
\text { materials in a } \\
\text { variety of formats. }\end{array}$ & $\begin{array}{l}\text { B10. Ability to } \\
\text { independently } \\
\text { learn how to use } \\
\text { new technology } \\
\text { and software. }\end{array}$ & $\begin{array}{l}\text { B11. Use technology } \\
\text { to provide efficient } \\
\text { support to learners. }\end{array}$ & $\begin{array}{l}\text { B12. Have } \\
\text { knowledge of the } \\
\text { culture and local } \\
\text { practice to select the } \\
\text { most appropriate } \\
\text { technology. }\end{array}$ \\
\hline $\begin{array}{l}\text { B13. Explore } \\
\text { emerging } \\
\text { technologies for } \\
\text { learning. }\end{array}$ & $\begin{array}{l}\text { B14. Use features } \\
\text { of the technology } \\
\text { to enrich the } \\
\text { learning process } \\
\text { (geo location, } \\
\text { capture } \\
\text { information, etc.). }\end{array}$ & $\begin{array}{l}\text { B15. Adapt the } \\
\text { technology to the } \\
\text { needs of the learner. }\end{array}$ & \\
\hline
\end{tabular}

Figure 4. Use of digital technology competencies for the digital teacher.

Develop digital learning resources. As an expert in the field, teachers will need to develop digital learning resources for learners to access using technology. This study identified nine competencies in the develop digital learning resources area for the digital teacher (Figure 5).

\begin{tabular}{|l|l|l|l|l|}
\hline $\begin{array}{l}\text { C. Develop digital } \\
\text { learning resources }\end{array}$ & $\begin{array}{l}\text { C1. Have knowledge } \\
\text { of the content. }\end{array}$ & $\begin{array}{l}\text { C2. Select the } \\
\text { appropriate digital } \\
\text { technology to } \\
\text { match the content } \\
\text { and the learning } \\
\text { outcome. }\end{array}$ & $\begin{array}{l}\text { C3. Create high } \\
\text { quality digital } \\
\text { learning materials. }\end{array}$ & $\begin{array}{l}\text { C4. Develop } \\
\text { learning materials } \\
\text { to meet specific } \\
\text { learner's needs. }\end{array}$ \\
\hline & $\begin{array}{l}\text { C5. Develop } \\
\text { learning materials } \\
\text { vith limited } \\
\text { knowledge of the } \\
\text { learner (language, } \\
\text { culture, situation). }\end{array}$ & $\begin{array}{l}\text { C6. Identify } \\
\text { quality and valid } \\
\text { learning materials } \\
\text { for learners to } \\
\text { access. }\end{array}$ & $\begin{array}{l}\text { C7. Use different } \\
\text { strategies for } \\
\text { different learning } \\
\text { situations. }\end{array}$ & $\begin{array}{l}\text { C8. Use problem- } \\
\text { based learning to } \\
\text { develop learner's } \\
\text { high level } \\
\text { knowledge and } \\
\text { skills. }\end{array}$ \\
\hline & $\begin{array}{l}\text { C9. Sharelearning } \\
\text { resources with other } \\
\text { teachers. }\end{array}$ & \multicolumn{2}{l}{} \\
\hline
\end{tabular}

Figure 5. Develop digital learning resources compertencies for the digital teacher.

Re-mix learning resources. Because of the availability of open education resources, the teacher will have to select the appropriate learning resources and re-mix the resources to allow learners 
Ally

to achieve the learning outcomes. There are five re-mix learning resources competencies identified in this study (Figure 6).

\begin{tabular}{|l|l|l|l|l|}
\cline { 2 - 4 } $\begin{array}{l}\text { D. Re-mix digital } \\
\text { learning resources }\end{array}$ & $\begin{array}{l}\text { D1. Select } \\
\text { appropriate digital } \\
\text { learning resource } \\
\text { to maximize } \\
\text { learning. }\end{array}$ & $\begin{array}{l}\text { D2. Access } \\
\text { appropriate open } \\
\text { education } \\
\text { resources to } \\
\text { integrate into the } \\
\text { curriculum. }\end{array}$ & $\begin{array}{l}\text { D3. Modify the } \\
\text { learning resources } \\
\text { to align with the } \\
\text { learning outcome. }\end{array}$ & $\begin{array}{l}\text { D4. Re-mix open } \\
\text { education } \\
\text { resources to meet } \\
\text { the needs of } \\
\text { individual } \\
\text { learners. }\end{array}$ \\
\hline & $\begin{array}{l}\text { D5. Assess the } \\
\text { quality of open } \\
\text { education } \\
\text { resources. }\end{array}$ & & \\
\hline
\end{tabular}

Figure 6. Re-mix digital learning resources competencies for the digital teacher.

Communication. An important area of a teachers' responsibilities is communicating with learners using digital technology. The experts in this study identified four competencies under “Communication” (Figure 7).

\begin{tabular}{|l|l|l|l|l|}
\hline & $\begin{array}{l}\text { E1. Communicate at } \\
\text { the level of the } \\
\text { learner. }\end{array}$ & $\begin{array}{l}\text { E2. Use } \\
\text { appropriate non- } \\
\text { verbal } \\
\text { communication } \\
\text { when interacting } \\
\text { with learners } \\
\text { using two-way } \\
\text { video and text. }\end{array}$ & $\begin{array}{l}\text { E3. Model good } \\
\text { digital citizenship } \\
\text { when using social } \\
\text { media to } \\
\text { communicate with } \\
\text { learners and peers. }\end{array}$ & $\begin{array}{l}\text { E4. Communicate } \\
\text { in the language of } \\
\text { the learner. }\end{array}$ \\
\hline
\end{tabular}

Figure 7. Communication competencies for the digital teacher.

Facilitate learning. The "facilitate learning" area has the largest number of competencies (29; Figure 8), which is an indication that a major role of the digital teacher will be as a facilitator of learning. In the digital era, learners will be learning virtually where there is a physical separation of the digital teacher and the learners.

\begin{tabular}{|l|l|l|l|l|}
\hline F. Facilitate Learning & $\begin{array}{l}\text { F1. Personalize the } \\
\text { learning for } \\
\text { individual learners. }\end{array}$ & $\begin{array}{l}\text { F2. Respond to } \\
\text { learners' } \\
\text { questions in a } \\
\text { timely manner. }\end{array}$ & $\begin{array}{l}\text { F3. Ability to } \\
\text { change strategies on } \\
\text { the fly when } \\
\text { supporting the } \\
\text { learner to meet the } \\
\text { learner needs. }\end{array}$ & $\begin{array}{l}\text { F4. Respect } \\
\text { different learner } \\
\text { types and adapt to } \\
\text { the learner. }\end{array}$ \\
\hline $\begin{array}{llll}\text { F5. Encourage } \\
\text { creativity. }\end{array}$ & $\begin{array}{l}\text { F6. Encourage } \\
\text { innovation. }\end{array}$ & $\begin{array}{l}\text { F7 Be a good } \\
\text { listener. }\end{array}$ & $\begin{array}{l}\text { F8. Provide } \\
\text { appropriate } \\
\text { feedback. }\end{array}$ \\
\hline $\begin{array}{l}\text { F9. Show } \\
\text { enthusiasm about } \\
\text { the learning } \\
\text { materials. }\end{array}$ & $\begin{array}{l}\text { F10. Model } \\
\text { working in the } \\
\text { digital age. }\end{array}$ & $\begin{array}{l}\text { F11. Motivate } \\
\text { students to learn. }\end{array}$ & $\begin{array}{l}\text { F12. Encourage } \\
\text { social interaction } \\
\text { between learners. }\end{array}$ \\
\hline $\begin{array}{l}\text { F13. Ability to } \\
\text { formulate good } \\
\text { questions when } \\
\text { interacting with } \\
\text { learners. }\end{array}$ & $\begin{array}{l}\text { F14. Model good } \\
\text { virtual behavior. }\end{array}$ & $\begin{array}{l}\text { F15. Be } \\
\text { approachable. }\end{array}$ & $\begin{array}{l}\text { F16. Promote and } \\
\text { model digital } \\
\text { citizenship and } \\
\text { responsibility. }\end{array}$ \\
\hline
\end{tabular}


Ally

\begin{tabular}{|c|c|c|c|}
\hline $\begin{array}{l}\text { F17. Encourage } \\
\text { authentic learning. }\end{array}$ & $\begin{array}{l}\text { F18. Inspire } \\
\text { learners. }\end{array}$ & $\begin{array}{l}\text { F19. Create a } \\
\text { comfortable } \\
\text { learning } \\
\text { atmosphere. }\end{array}$ & $\begin{array}{l}\text { F20. Provide } \\
\text { feedback to } \\
\text { individual learners } \\
\text { to meet their } \\
\text { individual needs. }\end{array}$ \\
\hline $\begin{array}{l}\text { F21. Interpret } \\
\text { learner dashboard } \\
\text { to monitor each } \\
\text { learner } \\
\text { performance. }\end{array}$ & $\begin{array}{l}\text { F22. Interpret } \\
\text { learner's question. }\end{array}$ & $\begin{array}{l}\text { F23. Solve learner's } \\
\text { problems. }\end{array}$ & $\begin{array}{l}\text { F24. Provide } \\
\text { support to learners } \\
\text { who are on the go. }\end{array}$ \\
\hline $\begin{array}{l}\text { F25. Act as a coach } \\
\text { for learners. }\end{array}$ & $\begin{array}{l}\text { F26. Act as a } \\
\text { mentor for } \\
\text { learners. }\end{array}$ & $\begin{array}{l}\text { F27. Support } \\
\text { learners using } \\
\text { digital technology. }\end{array}$ & $\begin{array}{l}\text { F28. Be an expert } \\
\text { in the content to } \\
\text { help learners who } \\
\text { will be at different } \\
\text { points in the } \\
\text { learning process. }\end{array}$ \\
\hline $\begin{array}{l}\text { F29. Encourage } \\
\text { learners to think } \\
\text { outside the box. }\end{array}$ & & & \\
\hline
\end{tabular}

Figure 8. Facilitation competencies for the digital teacher.

Pedagogical strategies. The teacher has to use appropriate pedagogical strategies to allow students to achieve the learning outcomes. The "Pedagogical Strategies" area has 12 competencies for the digital teacher (Figure 9).

\begin{tabular}{|l|l|l|l|l|}
\hline $\begin{array}{l}\text { G. Pedagogical } \\
\text { strategies }\end{array}$ & $\begin{array}{l}\text { G1. Use appropriate } \\
\text { pedagogical } \\
\text { approach to match } \\
\text { the technology. }\end{array}$ & $\begin{array}{l}\text { G2. Use } \\
\text { appropriate } \\
\text { learning theory to } \\
\text { develop learning } \\
\text { strategies to } \\
\text { maximize } \\
\text { learning. }\end{array}$ & $\begin{array}{l}\text { G3. Offer choices } \\
\text { and multiple } \\
\text { options for } \\
\text { presenting concepts } \\
\text { through resources } \\
\text { and support } \\
\text { options. }\end{array}$ & $\begin{array}{l}\text { G4. Prescribe } \\
\text { learning activities } \\
\text { for individual } \\
\text { learners. }\end{array}$ \\
& $\begin{array}{l}\text { G5. Use appropriate } \\
\text { collaborative online } \\
\text { learning } \\
\text { frameworks to } \\
\text { encourage } \\
\text { interaction between } \\
\text { learners and } \\
\text { between the teacher } \\
\text { and the learner. }\end{array}$ & $\begin{array}{l}\text { G6. Suggest } \\
\text { remedial activities } \\
\text { to help learners } \\
\text { who need them. }\end{array}$ & $\begin{array}{l}\text { G7 Use a variety of } \\
\text { learning strategies } \\
\text { to develop high } \\
\text { level knowledge and } \\
\text { skills. }\end{array}$ & $\begin{array}{l}\text { G8. Use interactive } \\
\text { strategies such as } \\
\text { serious games and } \\
\text { simulations to } \\
\text { motivate learners. }\end{array}$ \\
\hline $\begin{array}{l}\text { G9. Engage learners } \\
\text { during the learning } \\
\text { process. }\end{array}$ & $\begin{array}{l}\text { G10. Suggest } \\
\text { additional } \\
\text { learning activities } \\
\text { for learners who } \\
\text { need them. }\end{array}$ & $\begin{array}{l}\text { G11. Use problem- } \\
\text { based learning to } \\
\text { encourage high level } \\
\text { learning. }\end{array}$ & $\begin{array}{l}\text { G12. Encourage } \\
\text { learners to learn } \\
\text { independently. }\end{array}$ \\
\hline
\end{tabular}

Figure 9. Pedagogical strategies competencies for the digital teacher.

Assess learning. The teacher must provide feedback to learners and assess learner's performance using appropriate assessment strategies. The assessment must be authentic to improve learners' performance and to allow learners to receive academic credit for the lessons or courses they will complete (Conrad \&Openo, 2018). The "Assess Learning” area has four competencies for the digital teacher (Figure 10). 
Ally

\begin{tabular}{|l|l|l|l|l|}
\hline H. Assess learning & $\begin{array}{l}\text { H1. Select } \\
\text { assessment } \\
\text { strategies to match } \\
\text { the learning } \\
\text { outcomes. }\end{array}$ & $\begin{array}{l}\text { H2. Use } \\
\text { assessment } \\
\text { strategies to } \\
\text { measure learners' } \\
\text { performance. }\end{array}$ & $\begin{array}{l}\text { H3. Use virtual } \\
\text { assessment } \\
\text { strategies to assess } \\
\text { performance. }\end{array}$ & $\begin{array}{l}\text { H4. Provide } \\
\text { feedback to } \\
\text { learners. }\end{array}$ \\
\hline
\end{tabular}

Figure 10. Assessing learning competencies for the digital teacher.

Personal characteristics. The digital teacher should have personal characteristics to be a good role model, provide quality education, and support to learners. This study identified 15 personal characteristics competencies for the digital teacher (Figure 11).

\begin{tabular}{|l|l|l|l|l|}
\hline \begin{tabular}{|l|l|} 
I. Personal \\
characteristics
\end{tabular} & $\begin{array}{l}\text { I1. Be socially } \\
\text { responsible for the } \\
\text { use of resources and } \\
\text { be environmentally } \\
\text { friendly. }\end{array}$ & $\begin{array}{l}\text { I2. Be a good role } \\
\text { model for } \\
\text { learners. }\end{array}$ & $\begin{array}{l}\text { I3. Work in virtual } \\
\text { teams to share } \\
\text { information with } \\
\text { other teachers. }\end{array}$ & $\begin{array}{l}\text { I4. Accept } \\
\text { innovation in the } \\
\text { learning system. }\end{array}$ \\
\hline $\begin{array}{l}\text { I5. Show } \\
\text { enthusiasm } \\
\text { virtually. }\end{array}$ & $\begin{array}{l}\text { I6. Be a lifelong } \\
\text { learner. }\end{array}$ & $\begin{array}{l}\text { I7 Keep learners' } \\
\text { information } \\
\text { confidential. }\end{array}$ & $\begin{array}{l}\text { I8. Consider } \\
\text { privacy issues and } \\
\text { keep learner } \\
\text { information. }\end{array}$ \\
\hline I9. Think digitally. & $\begin{array}{l}\text { I10. Be open- } \\
\text { minded. }\end{array}$ & $\begin{array}{l}\text { I11. Be sensitive to } \\
\text { learner's individual } \\
\text { differences. }\end{array}$ & $\begin{array}{l}\text { I12. Use good } \\
\text { social skills when } \\
\text { working virtually. }\end{array}$ \\
\hline $\begin{array}{l}\text { I13. Be flexible and } \\
\text { adaptable in the } \\
\text { modern digital age. }\end{array}$ & $\begin{array}{l}\text { I14. Show } \\
\text { empathy by } \\
\text { maintaining } \\
\text { humanity } \\
\text { virtually. }\end{array}$ & $\begin{array}{l}\text { I15. Model good } \\
\text { virtual behavior. }\end{array}$ & \\
\hline
\end{tabular}

Figure 11. Digital teacher personal characteristics.

\section{Conclusion}

Emerging digital technologies in education will continue to transform the delivery of education and the role of the teacher in individualized learning environments. Future education systems will be judged on how well the system prepares learners to function in the $21{ }^{\text {st }}$ century world and in the Fourth Industrial Revolution rather than how many graduates are produced. This research contributes to future education by developing a competency profile to train teachers. There is a gap between how teachers currently instruct and what will be required of teachers in the future (Bezuidenhout, 2018). Hopefully, the competencies presented in this study will help to identify that gap so that relevant teacher training is provided.

The digital teacher 2030 competency profile can be used by educational organizations and governments to develop training programs for the future and be used as a guide to inform "trainers of teachers" so that they can gain the expertise to effectively educate future teachers, as well as model the behaviors that teachers should use (Trust, 2017, 2018).

It is difficult to predict what technology will be available in the year 2030; however, trainers of teachers must stay abreast of emerging technologies. In the future, with artificial intelligence, robotics, and 
Ally

internet of things in the Fourth Industrial Revolution, human teachers may co-teach with robotic teachers. Future research will determine the role of the human teacher in such a relationship. Perhaps, in the near future, blended education will refer to the blending of human teachers with robotic teachers to provide quality education for all. 


\section{References}

Ally, M., \&Tsinakos, A. (2014). Increasing access through mobilelearning. Vancouver, Canada: Commonwealth of Learning.

Anagün, Ş. S. (2018). Teachers' perceptions about the relationship between 21st century skills and managing constructivist learning environments. International J ournal of Instruction, 11(4), 825-840. https:// doi.org/ 10.12973/iji.2018.11452a

Berry, B. (2018). The teachers of 2030: Creating a student-centered profession for the 21st century. Center for Teaching Quality. Retrieved from https:// files.eric.ed.gov/fulltext/ED509721.pdf

Bezuidenhout, A. (2018). Analysing the importance-competence gap of distance educators with the increased utilisation of online learning strategies in a developing world context. International Review of Research in Open and Distributed Learning, 19(3), 264-281. https:// doi.org/ 10.19173/irrodl.v19i3.3585

Boling, E. C., \&J . Beatty. (2010). Cognitive apprenticeship in computer-mediated feedback: Creating a classroom environment to increase feedback and learning. J ournal of Educational Computing Research, 43(1), 47-65. https:// doi.org/ 10.2190/EC.43.1.d

Bonnici, L.J ., Maatta, S.L., Klose, M.K., J ulien, H., \& Bajjaly, S. (2016). Instructional style and learner-centered approach: A cross-institutional examination of modality preference for online course delivery in a graduate professional program. Studies in Higher Education, 41(8), 1389- 1407. http:// dx.doi.org/ 10.1080/03075079.2014.977860

Campbell, C., \& Cameron, L. (2016). Scaffolding learning through the use of virtual worlds. In S. Gregory, M. J.W. Lee, B. Dalgarno, \& B. Tynan (Eds.), Learning in virtual worlds: Research and applications (pp. 241-259). Edmonton, Canada: AU Press. doi:10.15215/ aupress/9781771991339.01

Capuano, N., Gaeta, A., Guarino, G., Miranda, S., \&Tomasiello, S. (2016). Enhancing augmented reality with cognitive and knowledge perspectives: A case study in museum exhibitions. Behaviour \& Information Technology, 35(11), 968- 979. https:// doi.org/ 10.1080/ 0144929X.2016.1208774

Chai, C.S., \& Kong, S.C. (2017). Professional learning for 21st century education. J ournal of Computer in Education, 4(1), 1-4. DOI 10.1007/s40692-016-0069-y

Chen, M., Yu, S., \& Chiang, F. (2016). A dynamic ubiquitous learning resource model with context and its effects on ubiquitous learning. Interactive Learning Environments, 1-15. http:// dx.doi.org/ 10.1080/ 10494820.2016.1143846

Conrad, D., \& Openo, J . (2018). Assessment strategies for online learning: Engagement and authenticity. Edmonton, Canada: AU Press. doi:10.15215/ aupress/9781771992329.01 
Crompton, H., Lin, Y., Burke, D., \& Block, A. (2018). Mobile digital games as an educational tool in K12 schools. In S. Yu, M. Ally, \&A. Tsinakos (Eds.), Mobile and ubiquitous learning: An international handbook, 3-18. Singapore: Springer.

Cronin, C. (2017). Openness and praxis: Exploring the use of open educational practices in higher education. International Review of Research in Open and Distributed Learning, 18(5), 1534. https:// doi.org/ 10.19173/irrodl.v18i5.3096

De Troyer, Q., Van Broeckhoven, F., \& Vlieghe, J (2017). Linking serious game narratives with pedagogical theories and pedagogical design strategies. J ournal of Computing in Higher Education, 29, 549-573. DOI 10.1007/ s12528-017-9142-4

Dyer, C. (2016). Evolving approaches to educating children from nomadic communities. Prospects, 46, 39- 54. DOI 10.1007/ s11125-016-9381-6

Ehlers, U. D. (2011). Extending the territory: From open educational resources to open educational practices. J ournal of Open, Flexible and Distance Learning, 15(2). Retrieved from http:// www.editlib.org/p/ 147891/

Farias, G. (2016). Large-scale deployment of tablet computers in Brazil: An implementation model for school districts (Unpublished Doctoral Dissertation). Athabasca University, Athabasca, Alberta.

Ferrández-Berrueco, R., \& Sánchez-Tarazaga, L. (2014). Teaching competences in Secondary Education. Analysis of teachers' profiles. RELIEVE, 20(1), 1-20. DOI:

10.7203/relieve.20.1.3786

Gaskell, A. (2018). Meeting sustainable development goal 4: Some key contributions. J ournal of Learning for Development, 5(1), 1-4. Retrieved from http://www.j14d.org/index.php/ ejl4d/article/view/ 287/295

Gros, B. (2016). The design of smart educational environments. Smart Learning Environments, 3(15), 2-11. DOI 10.1186/s40561-016-0039-x

Guo, H. (2018). Application of a computer-assisted instruction system based on constructivism. International J ournal of Emerging Technology in Learning, 13(4), 33-44. https:// doi.org/ 10.3991/ijet.v13i04.8468

Halterbran, V.R. (2017). Lessons in learning. Adult Learning, 28(1), 12-19. https:// doi.org/ 10.1177/ 1045159516643942Lifelong

Hinzen, H., \& Schmitt, S. (2016). Agenda 2030 - Education and lifelong learning in the sustainable development goals. Bonn, Germany: DVV International. Retrieved from https://www.dvvinternational.de/fileadmin/files/Inhalte_Bilder_und_Dokumente/Materialien/IPE/IPE 75 EN_web.pdf

Huang, R. (2018, March). Mainstreaming digital skills to embrace the digital era. Paper presented at the UNESCO Mobile Learning Week, Paris. 
Hwang, G. (2014). Definition, framework and research issues of smart learning environments - a context-aware ubiquitous learning perspective. Smart Learning Environments, 1(4), 1-14. doi:10.1186/s40561-014-0004-5

Hunt, N.P. (2006). Using technology to prepare teachers for the twenty-first century. Asia-Pacific J ournal of Teacher Education, 25(3), 345-350. DOI: 10.1080/ 1359866970250309

Inverso, D.C., Kobrin, J ., \&Hashmi, S. (2017). Leveraging technology in adult education. J ournal of Research and Practice for Adult Literacy, Secondary, and Basic Education, 6(2), 55-58.

Kolenick, P. (2018). Adult education in the post-secondary context: Sustainability in the 21st century. Alberta J ournal of Educational Research, 64(2), 208-213.

Kong, S., Looi, C.K., Chan, T.W., \& Huang, R. (2017). Teacher development in Singapore, Hong Kong, Taiwan, and Beijing for e-learning in school education. J ournal of Computer in Education, 4(1), 5-25. DOI: 10.1007/ s40692-016-0062-5

Kramer, A., \& Tamm, M. (2018). Does learning trigger learning throughout adulthood? Evidence from training participation of the employed population. Economics of Education Review, 62, 8290. https:// doi.org/10.1016/j.econedurev.2017.11.004

McGreal, R. (2017). Special Report on the role of open educational resources in supporting the sustainable development goal 4: Quality education challenges and opportunities. International Review of Research in Open and Distributed Learning, 18(7), 292-305. https:// doi.org/ 10.19173/irrodl.v18i7.3541

Maldonado-Mahauad, J ., Perez-Sanagustín, M., Kizilcec, R.F., Morales, N., \& Munoz-Gama, J . (2018). Mining theory-based patterns from big data: Identifying self-regulated learning strategies in Massive Open Online Courses. Computers in Human Behavior, 80, 179-196. https:// doi.org/ 10.1016/j.chb.2017.11.011

McWilliams, S.A. (2016). Cultivating constructivism: Inspiring intuition and promoting process and pragmatism. J ournal of Constructivist Psychology, 29(1), 1- 29. https:// doi.org/ 10.1080/ 10720537.2014.980871

Mitra, S. (2014). The future of schooling: Children and learning at the edge of chaos. Prospects 44, 547- 558. DOI 10.1007/s11125-014-9327-9

Parong, J . \& Mayer, R.E. (2018). Learning science in immersive virtual reality. J ournal of Educational Psychology, 110(6), 785-797. http:// dx.doi.org/ 10.1037/ edu0000241

Paskevicius, M., \&Hodgkinson-Williams, C. (2018). Student perceptions of the creation and reuse of digital educational resources in a community development-oriented organisation. J ournal of Learning for Development, 5(1), 22-39. Retrieved from http:// www.j14d.org/index.php/ ej14d/article/view/253/283

Patterson, M.B. (2018). The forgotten 90\%: Adult nonparticipation in education. Adult Education Quarterly, 68(1), 41-62. DOI: 10.1177/0741713617731810 
Popenici, S.D. \& Kerr, S. (2017). Exploring the impact of artificial intelligence on teaching and learning in higher education. Research and Practice in Technology Enhanced Learning, 12(22), 1-13. DOI 10.1186/s41039-017-0062-8

Qatar Foundation. (2014). 2014 WISE survey: School in 2030. Retrieved from https:// www.wiseqatar.org/sites/default/files/ wise-survey-school-in-2030.pdf

Redecker, C. (2017). European framework for the digital competence of educators. Luxembourg: Publications Office of the European Union.

Reyna, J ., Hanham, J ., \& Meier, P. (2018). The Internet explosion, digital media principles and implications to communicate effectively in the digital space. E-Learning and Digital Media, 15(1), 36-52. DOI 10.1177/2042753018754361

Schmidt, V.H. (2017). Disquieting uncertainty: Three glimpses into the future. European J ournal of Futures Research, 5(6), 1-10. DOI 10.1007/ s40309-017-0113-9

Srinivasan, S. (2017). The future of mobile learning. Media Development, 1, 16-19.

Suárez, A., Specht, M., Prinsen, F., Kalz, M., \&Ternier, S. (2018). A review of the types of mobile activities in mobile inquiry-based learning. Computers and Education, 118, 38-55. https:// doi.org/ 10.1016/j.compedu.2017.11.004

Trust, T. (2017). Preparing future teachers to redefine learning with technology. J ournal of Digital Learning in Teacher Education, 33(2), 44-45. DOI: 10.1080/21532974.2017.1281654

Trust, T. (2018). Why do we need technology in education? J ournal of Digital Learning in Teacher Education, 34(2), 54-55, DOI: 10.1080/21532974.2018.1442073

UNESCO. (2015). Incheon declaration. Education 2030: Towards inclusive and equitable quality education and lifelong learning for all. Retrieved from http:// www.unesco.org/new/fileadmin/MULTIMEDIA/HQ/ED/ED/pdf/FFA_Complet_We b-ENG.pdf

World Economic Forum. (2017, J anuary). Realizing human potential in the fourth industrial revolution: An agenda for leaders to shape the future of education, gender and work (White paper). Retrieved from http:// www3.weforum.org/docs/WEF EGW Whitepaper.pdf

Yam, S. C., Swati, M., \&J ing, C.O. (2014). Professional development for scaling pedagogical innovation in the context of game-based learning: Teacher identity as cornerstone in "shifting" practice, Asia-Pacific J ournal of Teacher Education, 43(5), 423-437, DOI: $\underline{10.1080 / 1359866 X .2014 .962484}$

Yoon, S., Anderson, E., Lin, J ., \& Elinich, K. (2017). How augmented reality enables conceptual understanding of challenging science content. Educational Technology \& Society, 20(1), 156168. Retrieved from https://www.j-ets.net/ETS/journals/ 20 1/14.pdf 
Ally

Yu, S., Ally, M. \& Tsinakos, A. (2018). Mobile and ubiquitous learning: An international handbook. Singapore: Springer.

Yu, S., Yang, X., Cheng, G., \&Wang, M. (2015). From learning object to learning cell: A resource organization model for ubiquitous learning. Educational Technology \& Society, 18(2), 206224. Retrieved from https:// www.j-ets.net/ETS/journals/ 18 2/ 16.pdf

\section{Athabasca}

University

(c) (1) 